\title{
Impact of Climate Change to Tourism Sector in the Vietnamese Mekong Delta
}

\author{
Van Da Huynh ${ }^{1}$, Awais Piracha \& Hayley Saul ${ }^{2}$ \\ ${ }^{1}$ School of Social Sciences and Humanities, Can Tho University, Can Tho, Vietnam \\ ${ }^{2}$ School of Social Sciences and Psychology, Western Sydney University, Sydney, Australia \\ Correspondence: Van Da Huynh, School of Social Sciences and Humanities, Can Tho University, Campus 2, 3/2 Street, \\ Ninh Kieu District, Can Tho City, Vietnam. E-mail: hvda@ctu.edu.vn
}

Received: September 8, 2019 Accepted: September 29, 2019 Online Published: November 6, 2019

doi:10.5539/res.v11n4p44

URL: https://doi.org/10.5539/res.v11n4p44

\begin{abstract}
Mekong Delta Region of Vietnam is forecasted to have one of world's most severe impacts from climate change. There is a big knowledge gap in research on climate change impacts on tourism in this area. While climate change's impacts on agriculture and fisheries have received much attention from authorities and researchers, impacts on tourism have largely been ignored. This paper presents findings from a field study the authors conducted to fill the research gap on climate change's impact on tourism in Mekong River Delta. The study based on spatial analysis and questionnaires and interviews of local tourism leaders, tourism businesses and tourists discovered that climate change is a real challenge for region's tourism businesses. Vulnerable tourism businesses in low and flat delta such as Mekong needs more attention and practical actions from international organizations and local entities in the era of climate change threats.
\end{abstract}

Keywords: climate change, climate change impact, Mekong Delta, tourism

\section{Introduction}

Climate change is one of the most complex challenges in 21 st Century and failure to meet this challenge raises the spectre of unprecedented reversals in human development. Tourism is a highly climate dependent industry. The tourism sector has received considerable attention in the reports of the IPCC Working Group on Impacts, Adaptation and Vulnerability. However, this report indicates that 'Knowledge of the capacity of current climate adaptations utilized by the tourism sector to cope successfully with future climate change is currently very limited'(UNWTO, UNEP, \& WMO, 2008, p. 102). Simpson, Gössling, Scott, Hall, and Gladin (2008) noted that tourism and climate change research literature has been much fulfilled in the 2000s decade. Nevertheless, there are gaps in the current knowledge about how to undertake climate change adaptation and mitigation, particularly in developing countries and small islands. The connections between tourism and climate change are less well-understood in the developing world than in countries with more established tourism histories. Meanwhile, tourism industries in these territories are some of the most vulnerable to climate change.

More recently, debates have shifted to consider effective modes of adaptation and the complex role that tourism might play in this. Literature on climate change impacts on the tourism sector indicates that there is a big knowledge gap in term of geographic distribution of studies. Most of climate-tourism research focuses on the mountains and coastal areas. A main consequence of climate change in mountain areas is rapid melting of snow and its consequences (Hendrikx, Zammit, Hreinsson, \& Becken, 2013; Steiger \& Stötter, 2013). Effects of climate change on coastal areas are more complicated. They include increase of mean air temperature and sunshine duration (Surugiu \& Surugiu, 2012) or warmer temperatures, rising sea levels, and more frequent and severe extreme weather events (Lewsey, Cid, \& Kruse, 2004).

Climate change effects on tourism at delta regions such as the Mekong Delta have been given very little attention in scientific literature. The Mekong Delta Region of Vietnam is forecasted to face some of world's most severe impacts from climate change. Due to the low and flat of a typical river delta, tourism modes that are predominant in the Delta such as ecotourism, islet tourism, national parks tourism and mangrove forests tourism are highly vulnerable to climate change. Therefore, change impacts evaluation on tourism sector in such Delta will create a foundation for sustainable development in this region. This study explains the measurement and documentation of the impacts of climate change on tourism enterprises in the Mekong. 


\section{Research Background and Literature Review}

\subsection{Climate Change Impacts on Tourism}

The Davos Declaration on Climate Change and Tourism (UNWTO-UNEP-WMO, 2008) declared that climate change 'Must be considered the greatest challenge to the sustainability of tourism in the twenty-first century'. D. Scott, Hall, and Gössling (2012) note that climate is a resource and constraint for tourism. Moreover, tourism and climate have a close and complicated connection.

The connection between tourism and climate change has been researched for more than 25 years in tourism studies and recently the adaptation issues have been considered as an urgent need (Kaján \& Saarinen, 2013, p. 167; D Scott, 2011, p. 18). Scientific literature in the 2000s took up the issues of tourism as they relate to climate change (D. Scott, Wall, McBoyle, Hall, \& Higham, 2005). The relationship between tourism and climate change can be negative or positive. On the negative side tourism activities such as transportation, relaxation activities cause climate change and are vulnerable from it (Pang, McKercher, \& Prideaux, 2012, p. 4; D. Scott \& Becken, 2010). Climate change could cause extreme weather events, loss of biodiversity, ecosystem changes and topography changes. The changes may lead to social changes and reduction in environmental sustainability. In contrast, tourism is also considered as an avenue that can help to reduce the impact of climate change and could benefit from climate change (TITC, 2014). For example, the income from tourism activities may help communities to have a better preparation for climate change adaptation. Global warming is also increasing the length of summer on beach sites in subtropical areas. However, the negative side of climate change could outweigh the positive impacts.

There are several types of climate change impacts, including temperature, sea level rise, wind speeds, fire and precipitation. However, depending on geography, physical, social and economic factors, the impact is varying from region to region and destination to destination (Lew, Hall, \& Timothy, 2008; Simpson et al., 2008).

According to Kaján and Saarinen (2013) in the current decade the climate change, tourism and adaptation literature mainly focus on five themes: Businesses (Becken, 2005; Bicknell \& McManus, 2006; Dawson \& Scott, 2010; Hall, 2006), consumers (Coghlan \& Prideaux, 2009; Coombes \& Jones, 2010; Perry, 2006), destinations (Hamilton, 2007; Stewart, Dawson, \& Draper, 2011), policies (Pentelow \& Scott, 2011) and frameworks (Moreno \& Becken, 2009; Turton et al., 2010). The scale of tourism research is also from local to global and short-term to long-term.

In terms of the geographic distribution of research areas, almost all former studies focus on coastal zones (Buzinde, Manuel-Navarrete, Yoo, \& Morais, 2010; Coombes \& Jones, 2010) and mountainous areas (Bicknell \& McManus, 2006; D. Scott, McBoyle, Minogue, \& Mills, 2006). A number of studies in tourism literature have explored mountainous regions (Bicknell \& McManus, 2006; Dawson \& Scott, 2010; Pickering \& Buckley, 2010), hotels and resorts (Becken, 2005; Buzinde, Manuel-Navarrete, Kerstetter, \& Redclift, 2010; Hamilton, 2007), events (Jones, Scott, $\&$ Khaled, 2006) and beaches (Buzinde, Manuel-Navarrete, Yoo, et al., 2010; Coombes \& Jones, 2010). There is a gap in tourism and climate change literature when it comes to research on delta areas which are the most vulnerable from climate change. Weaver (2011) presents statistics that show from 1986 to 2009 there were 128 publications on climate and tourism concerns of which were $40 \%$ focused on winter-ski tourism, about $10 \%$ focus on small islands and coastal areas and 15\% focus on impacts of tourism on climate change via green-house gas emissions. Recently, publications on the impacts of climate change to beach and coastal areas caused by erosion and sea level rise are emerging for consideration in sustainable planning (Bigano, Bosello, Roson, \& Tol, 2008; Buzinde, Manuel-Navarrete, Yoo, et al., 2010; Schleupner, 2008).

In the context of the Mekong Delta, river islets are formed from the accumulation of alluvial material that happened after delta's development. Hence, these islets normally are lower than the average height of the Delta. If the sea water level rises, these islets will be some of the first landmass to be flooded. Following this, climate change will begin to affect national parks, fruit gardens and accommodation sites in the Mekong Delta. Overall, there is a likelihood that changes in traditional livelihoods will radically transform traditional culture and lifestyle.

\subsection{Climate Change and Tourism in the Mekong Delta of Vietnam}

Climate change and sea level rise scenarios for Vietnam were first introduced in 2009 by the Vietnam Ministry of Natural Resources and Environment. A National Strategy on Climate Change was issued subsequently in 2011 and its most recent publication was in 2016. These scenarios are syntheses of climate records and data analysis from national and international studies. Most of the Vietnam climate change scenarios are published by the Institute of Meteorology, Hydrology and Climate Change (IMHEN), Commonwealth Scientific and Industrial Research Organization (CSIRO) and Greater Mekong Delta Sub region (GMS). Although there are some minor differences in predicted outcomes due to difference in data collection methods and modeling, all scenarios contend that Vietnam will experience serious impacts from sea level rise, salinity intrusion, rainfall variations, temperature extremes and increasing tropical cyclones. 
Compare to other parts of Vietnam, Mekong Delta is the new historic area. Contemporary history of the Delta began about only 300 years ago. However, the area offers a wide range of tourism destinations including a range of natural heritage that showcases the region's biodiversity, to cultural heritage from southern Vietnam's rich prehistory, early historic and $20^{\text {th }}$ century wartime historic sites.

The Mekong Delta region has enormous natural and culture resources for tourism development. Around the Delta, there are 5 national parks, dozens of conservation areas and hundreds of fresh water fruit gardens. The Delta is covered by dense network of rivers, canals and islets. Moreover, dozens of floating markets, pagodas and temples serve as tourist attractions. Besides these tangible attractions, the intangible values such as cuisines and music also have a unique value for tourism activities in the Delta.

Tourism is a new but rapidly increasing industry in the Mekong Delta with annual development of $16.4 \%$ (Vietnam Tourism Institute, 2010). According to Pham (2013), the number of International tourists to the Mekong Delta in 2011 was more than 1.3 million, domestic tourists were more than 8 million and income from tourism was about3,500 billion VND (about 160 million USD). In 2013, there were about 1.7 million international tourists, 9 million domestic tourists and income from tourism reached 5,100 billion VND (about 250 million dollars) (Tran, 2015). In 2015, there are 1.8 million international tourists and 10.6 million domestic tourists visited Mekong Delta and income from tourism activities is around 8,500 billion VND (about 400 million USD). The tourism sector brings about $4 \%$ total GDP for the region.

\section{Research Methods}

This study employs both quantitative and qualitative methodologies for data collection, analysis and representation to approach the aims of the research. Therefore, a mixed method approach has been adopted in the study involving observation, survey questionnaires and in-depth interviews with the local tourism authorities, tourism companies and tourists. Data was mostly collected from primary sources. The secondary data is mostly from literature on the demographic characteristics of the region and mapping.

Due to the differences in background of respondents and purposes for information collection about climate change-tourism concern, a set of different questionnaires were designed for this study. These questionnaires include ones for leaders of local tourism authorities, managers of tourism companies and tourists. The study focuses on these three target groups since they are the most important stakeholders in Mekong Delta tourism. There are two main parts of these questionnaires: closed questions and open-ended questions. In these questionnaires, stakeholders are asked about their knowledge, experience and ideas on the climate change related issues as they relate to tourism in Mekong River Delta.

In total, about 124 respondents were conducted by the study, including: Local tourism authorities, tourism companies and tourists. The result is shown in Table1.

Table 1. Questionnaire collection outcomes

\begin{tabular}{l|l}
\hline & Number of respondents collected \\
\hline Authorities & 15 \\
\hline Businesses & 30 \\
\hline Tourists & 79 \\
\hline Total & 124
\end{tabular}

To supplement information collected with the questionnaires, in-depth interviews were conducted with local tourism authorities and tourism companies. The interviews were semi-structured, with open-ended questions following the themes of the research questions: What are possible impacts of climate change (to local tourism sector/to your business)? Thirty eight interviews were conducted for this study, including 15 interviews with local tourism authorities and 23 interviews with tourism companies. The interviews was conducted at the same time and same sample of questionnaire distribution.

Spatial analysis and GIS mapping tools were used to overlay climate change layers (ICEM, 2013) and tourism layers (Vietnam Tourism Institute, 2010) in the Mekong region. These two layers are the most official updated of climate change scenarios, tourism resources and destinations data in the Mekong Delta. The climate change layer is a raster image while tourism layer is vector data. Two GIS tools were used in this study: MapInfo Professional 10.0 and Arc Map 10.5.1. This method helped to identify the geographic areas and resources that are vulnerable under climate change. 


\section{Result}

\subsection{Type of Climate Change Impacts to Tourism Sector in the Mekong Delta}

\subsubsection{Sea Level Rise Impacts}

Although there has been much debate, it is generally agreed that global warming will lead to a complex array of consequences at varying global-local scales. One of the most remarkable problems of climate change is sea level rise (IPCC, 2001). In the tourism sector, sea level rise is already recognized as a significant influence in beach areas (Griffis \& Howard, 2013; Quante \& Colijn, 2016; Surugiu \& Surugiu, 2012). However, the influence of sea level rise on tourism in the Delta areas is still not fully understood.

Theoretical research pointed out that the main threat of climate change in the Mekong Delta is sea level rise. As consequences of a low and flat delta, Mekong Delta is one of the regions that suffer to serious impacts of climate change in the world. Spatial analysis of areas vulnerable to sea level rise (based on elevation data) and tourism destinations, as well as tourism resources, indicates the degree to which current tourism destinations and businesses are likely to be impacted by inundations in the Mekong Delta.

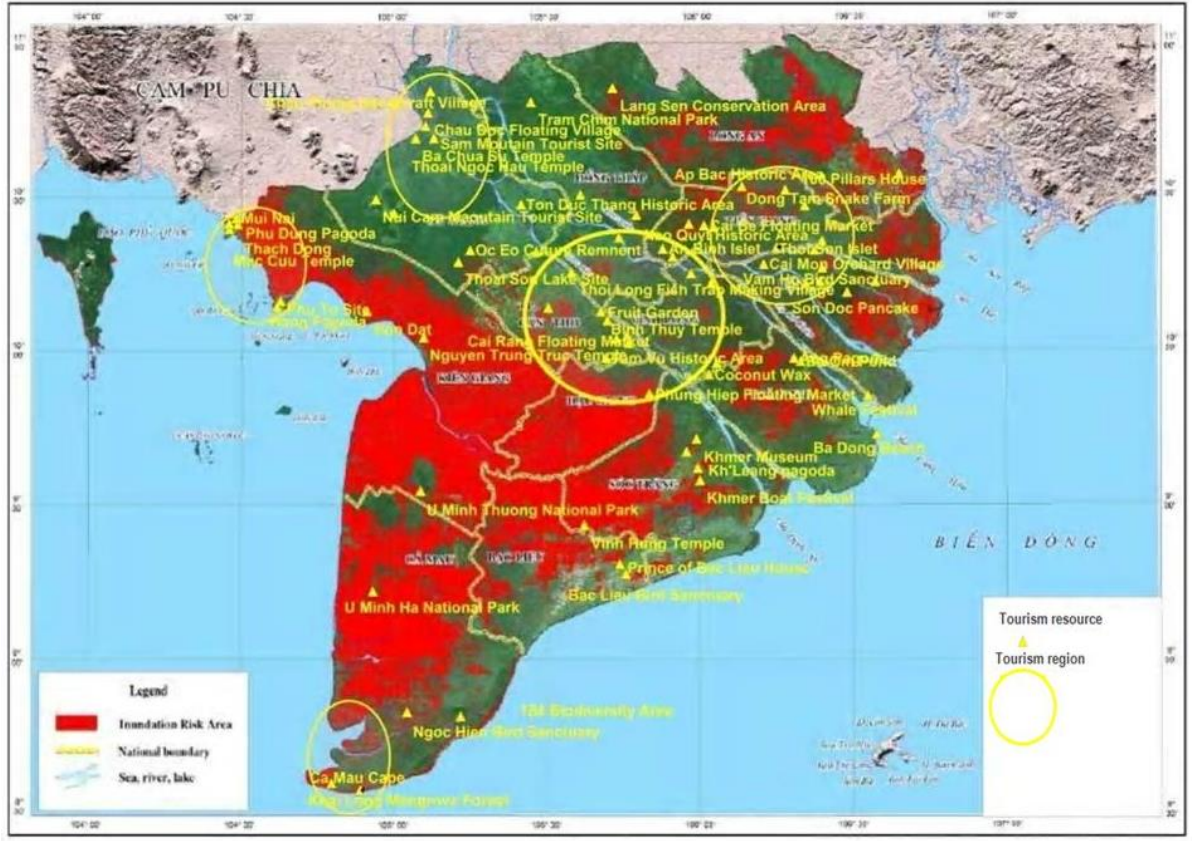

Figure 1. Impact of $100 \mathrm{~cm}$ sea level rise scenario to tourism destinations in the Mekong Delta

Source: Author's own work with the background map adapted from Ministry of Natural Resources and Environment (2016)

As shown in Figure 1, with a $100 \mathrm{~cm}$ sea level rise scenario, nearly $40 \%$ of the whole Delta will inundate. Tourism resources in the Delta have the same chance of impact. Twenty-one out of 36 tourism destinations of the region will be directly physically impacted by the $100 \mathrm{~cm}$ scenario (See Table 2). Nearly $60 \%$ of tourism destinations will experience primary or secondary impacts of a $100 \mathrm{~cm}$ sea level rise scenario. From that outcome, it can be concluded that the tourism sector in the region has more chance of being impacted than the average influenced by inundation of the Delta. Once again, the coastal areas would experience the biggest impact by this type of threat while the higher elevation parts of the Delta will be less effects to such damages in the $100 \mathrm{~cm}$ sea level rise scenario.

From the above analysis 21 destinations are impacted by sea level rise and are distributed almost evenly in 6 coastal provinces around the delta. There are 13 nature-based and 8 culture-based destinations. Data from in-depth interviews indicated that natural based resources, especially fresh water fruit gardens, would experience the strongest impact of sea level rise. The direct impact of sea level rise to fresh water fruit gardens is flooding and high salinity causing damage to orchards.

As indicated from a government authority respondent in the interview of the study: 'Sea level rise would inundate islands, coastal areas and many lower places leading to decline in tourist numbers. Sea water intrusion would cause lack of fresh water for agriculture that would lead to decreased attractiveness of the Delta.' (L01, interview, 2016). Clearly, sea level rise is a very big problem for tourism resources in the area. 
Table 1. Lists of tourism destinations impacted by inundation of $100 \mathrm{~cm}$

\begin{tabular}{lll}
\hline Order & Destinations & Locations \\
\hline Cai Be Floating Market & Cai Be \\
Tan Phong Islet & Cai Be \\
Binh Hoa Phuoc Islet & Long Ho \\
Truong An Tourist Site & Vinh Long \\
Dong Khoi Historic Area & Mo Cay \\
Ba Tri bird Sanctuary & Ba Tri \\
Cai Mon Orchard Village & Cho Lach \\
Phung Islet, Quy Islet & Chau Thanh \\
Oc Islet & Giong Trom \\
Ninh Kieu Quay & Ninh Kieu \\
Cai Rang Floating Market & Cai Rang \\
Phong Dien Floating Market & Phong Dien \\
Phu Tu islet-Hang Pagoda & Ha Tien \\
Nguyen TrungTruc Temple & Rach Gia \\
Tam Bao Pagoda & Rach Gia \\
Thach Dong & Ha Tien \\
Mui Nai & Ha Tien \\
Hon Dat & Hon Dat \\
Bac Lieu bird Sanctuary & Bac Lieu \\
Vinh Hung Temple & Vinh Loi \\
\hline
\end{tabular}

Source: Author's own work

Sea level rise is expected to be a primary concern of climate change in the region. The study evaluated stakeholders' knowledge and opinion about the possible impact of sea level rise on tourism businesses $(n=121)$. Nearly $60 \%$ of people agreed that sea level will increase. On the other hand, more than $27 \%$ of respondents thought that sea level will impact irregularly and the remaining 13\% thought the sea level will decrease. A combination of 'increase and irregular' sea level rise perception leads to a significant statistic which nearly $90 \%$ of the region would suffer to bad impact of sea level rise according to above data. Hence, sea level rise is not deniable in the tourism sector in the region.

\subsubsection{Salinity Impacts}

Salinity is the presence of salt in the land surface, in soil or rocks, or dissolved in water in rivers or groundwater (NSW office of Environment and Heritage, 2018). Salinity probably has more impact in the coastal low and flat regions. The consequences of salinity are loss of biodiversity and changes in livelihoods (Wabnitz et al., 2018) due to damage of rice farms, fruit gardens and ground water (Neffati, Sriti, Hamdaoui, Kchouk, \& Marzouk, 2011).

In the case of the Vietnamese Mekong Delta salinity is defined as the intrusion of sea water into land surface. Salinity intrusion has increased the salt content of water in Mekong Delta through condense river systems. Salinity is evaluated at many levels. In the Mekong Delta, the $4 \mathrm{~g} / \mathrm{l}$ salinity is the most common threshold at which the salinity could destroy the fresh water ecosystems such as rice systems or fruit gardens system (Ministry of Natural Resources and Environment, 2008).

In the baseline salinity intrusion case of 1996, only around ten coastal destinations are impacted. Coastal destinations in Ca Mau, Bac Lieu, Ben Tre and Tra Vinh tend to be impacted by this salinity. However, the traditional ecosystems of these areas are normally mangroves and are under impact of salt water from the sea. Therefore, the impact of this salinity is slight and can be naturally adapted to by these destinations. For a long period of time, the tourism industry here has been based on mangrove forests and salt water ecosystems.

However, in $50 \mathrm{~cm}$ sea level rise scenario there is a significant change in the number of tourism destinations being impacted by salinity. In this scenario, $45 \%$ of the delta will be impacted by salinity of $4 \mathrm{~g} / \mathrm{l}$. Thus, tourism destinations in the region will be significantly impacted. In this case the tourism destinations located in the center of the region which are based on the fresh water fruit gardens will be impacted.

In the salinity intrusion scenario of $50 \mathrm{~cm}, 20$ out of 36 principal tourism destinations of the region are affected. Once again, it needs to be made clear that not all of destinations will be destroyed by this scenario due to their natural adaption capacity. However, many of them would be challenged to shift from a fresh water system to the saline water one. The destinations in Vinh Long, Ben Tre and Can Tho seem to experience the strongest effects.

In a $100 \mathrm{~cm}$ salinity scenario, $60 \%$ of the delta will be impacted by $4 \mathrm{~g} / \mathrm{l}$ salinity. In that scenario, intrusion climbs further to the upper streams of the delta (Figure 2). Thus, a huge number of tourism destinations will be impacted. Spatial analysis found that as well as the coastal tourism regions all the central tourism regions will suffer the influence from $100 \mathrm{~cm}$ salinity. In particular, the biggest tourism hotspot of the region, Can Tho City, will suffer to inundations by this scenario. 


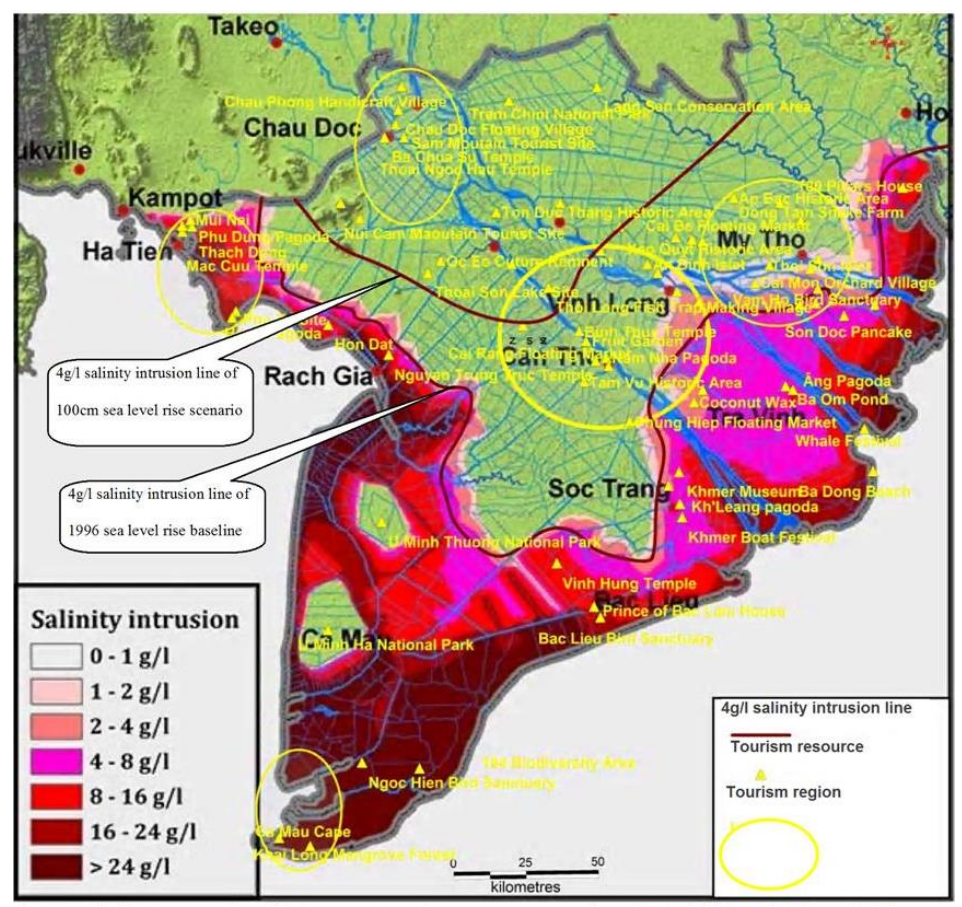

Figure 2. Impact of salinity to tourism resources in the Mekong Delta, $100 \mathrm{~cm}$ sea level rise scenario

Source: Author's own work with the background map adapted from Mekong River Commission data and information services (2017), salinity intrusion baseline is in 1996

The findings of this analysis clearly indicate that an enormous number of tourism destinations will be impacted from $100 \mathrm{~cm}$ salinity. Table 2 illustrates 27 out of 36 tourism destinations of regions, except the ones at An Giang province, threatened by a $100 \mathrm{~cm}$ salinity intrusion. There is no doubt that in this scenario salinity has a critical influence on tourism activities in almost the entire region.

Table 2. Lists of tourism destinations impact by salinity of $100 \mathrm{~cm}$

\begin{tabular}{|c|c|c|}
\hline Order & Destinations & Locations \\
\hline & Long An Museum & Tan An \\
\hline & Moc Hoa Snake Farm & Moc Hoa \\
\hline & Vinh Trang pagoda & My Tho \\
\hline & Thoi Son Islet & My Tho \\
\hline & Dong Tam Snake Farm & Chau Thanh \\
\hline & Cai Be Floating Market & Cai Be \\
\hline & Tan Phong Islet & Cai Be \\
\hline & Binh Hoa Phuoc Islet & Long Ho \\
\hline & Truong An Tourist Site & Vinh Long \\
\hline & Dong Khoi Historic Area & Mo Cay \\
\hline & Ba Tri bird Sanctuary & Ba Tri \\
\hline & Cai Mon Orchard Village & Cho Lach \\
\hline & Phung Islet, Quy Islet & Chau Thanh \\
\hline & Oc Islet & Giong Trom \\
\hline & Ninh Kieu Quay & Ninh Kieu \\
\hline & Cai Rang Floating Market & Cai Rang \\
\hline & Phong Dien Floating Market & Phong Dien \\
\hline & Mekong Delta Rice Institute & O Mon \\
\hline & Can Tho University & Ninh Kieu \\
\hline & PhuTu islet-Hang Pagoda & Ha Tien \\
\hline & Nguyen TrungTruc Temple & Rach Gia \\
\hline & Tam Bao Pagoda & Rach Gia \\
\hline & Thach Dong & Ha Tien \\
\hline & Mui Nai & Ha Tien \\
\hline & Hon Dat & Hon Dat \\
\hline & Bac Lieu bird Sanctuary & Bac Lieu \\
\hline & Vinh Hung Temple & Vinh Loi \\
\hline
\end{tabular}

Source: Author's own work 
This spatial analysis has identified the number of tourism sites that are impacted by salinity and sea level rise, indicating the scale of threats to tourism under different climate change scenarios. It has also investigated whether certain types of tourism destinations are more vulnerable than others. Expanding upon this spatial analysis the survey of authorities, businesses, and tourists was also useful to understand in detail local observations of climate change impacts within the different stakeholder groups $(n=121)$. In this analysis, $77.7 \%$ of people had witnessed water and soil salinity increases in their local areas. This is substantially greater that the $11.6 \%$ who experienced a decrease in salinity and $10.7 \%$ who recorded an irregular impact of salinity. Consequently, observed increases in salinity dominated local experiences. In this observation, the salinity increase is result in the death of fresh water rice farms or fruit gardens. Furthermore, a combination of an increase and irregular salinity the percentage reaches $88 \%$. This is a very high and highly meaningful statistic in term of impact of salinity to tourism sector of the region.

\subsubsection{Temperature Impacts}

Tourism is a climate-based industry. Many people travel for the purposes of enjoying fresh environments and warm temperatures. As such, temperature is an important indicator in destination choice. Temperature has direct impact on tourism activities, especially outdoor activities (Craig \& Feng, 2018). Temperature variations may have a strong effect on the flow of tourists (Rosselló-Nadal, Riera-Font, \& Cárdenas, 2011). The Mekong Delta region is normally ideal for the travelers who search for a tropical climate with consistent temperature of around $28^{0} \mathrm{C}$ and a clean air. However, climate change is predicted to alter this climate pattern by increasing temperature or making it more variable. The results of the survey support this concern. When asked if they had witnessed a change in average temperatures recently $66.1 \%$ of respondents perceived an increase in temperature around their homes and businesses while $10.7 \%$ experienced a decrease and $23.1 \%$ stated that they experienced irregular temperature. Nearly $90 \%$ of people that experienced increased or irregular temperatures indicate that perceived temperature rises are a wide scale phenomenon in the Mekong region. As such temperature has the potential to reduce the appeal of the region and impact tourism development.

\subsubsection{Rainfall Impacts}

Rainfall is another climate pattern that can also directly or indirectly influence the destination choice of holiday makers. The direct impact is that the rainfall may reduce the number and quality of outdoor activities for tourists (Craig \& Feng, 2018) and influence the demand for tourism destinations that are outdoors (Aylen, Albertson, \& Cavan, 2014). The indirect impact is that changes in rainfall could alter ecosystems, drastically destabilizing a destination, particularly those that celebrate natural heritage. In the case of Mekong Delta, quantities of rainfall vary substantially between regions. When asked whether they could perceive changes in rainfall patterns $18.0 \%$ of respondents to the survey indicated that they considered rainfall to have increased, while $27.9 \%$ had experienced a decrease in it. Surprisingly, $54.1 \%$ of respondents experienced rainfall as more irregular than previously, suggesting that perhaps the consistency of weather patterns had altered and the intensity of precipitation when rainfall did occur. Compared to temperature indicators, the survey indicates that rainfall in the Mekong Delta has become much more varied and unpredictable recently. This result suggests that this climate change factor could pose more of a regional challenge to tourism than has previously been anticipated.

\subsubsection{Storm Impacts}

Located in the tropics, the Mekong frequently suffers from tropical storms (also called typhoons). Like temperature impacts, tourism activities are sensitive to extreme and sudden weather events like storms. Unlike temperature and rainfall impacts, a storm may cause more threats by increasing infrastructure damage and moving along unpredictable tracks (James, 2018). Therefore, in most cases storm impacts draw the attention of both holiday makers and tourism organizers. The same has happened in the Mekong region. Climate change research indicates that the typhoon track in Vietnam has moved towards more southern areas, more strong storms occurred in the last decades and typhoon season now ends later (Ministry of Natural Resources and Environment, 2008). In the survey of tourists and tour organizers the feedback on the possible impact of storms to the region is highly recognized. Result shows that $31.1 \%$ of people experienced an increase in storm activity whilst is only $9.8 \%$ of people experienced a decrease in storms in the region. Overall though, 59\% of people experienced storm activity in the region as having developed irregular characteristics. This irregularity was mentioned in the in-depth interviews session. Many respondents were concerned the storm season may arrive sooner or later or more storms with strong wind may occur much more frequently (B03, B06, B07, interview, 2016).

Expanding on the results of the questionnaire the in-depth interviews that were conducted with authorities and local businesses gave a more comprehensive local explanation for how these irregular storm surges were affecting lifestyles and tourism businesses. One of question in the interviews was: What are the possible impacts of climate change to the local tourism sector/to your business? Thirty-eight responses were collected. Respondents mentioned a variety of effects of climate change to the tourism industry of the region. The possible consequences of climate change impacts described 
by the respondents are listed in priority order as the following: 1) bad impacts on tourism resources; 2) bad impacts on tourism facilities and 3) bad impacts on tourism activities. It was observed that the consequences of these impacts have led to a decrease in tourist numbers and a decrease in economic returns. Some remarkable responses were as following:

'Increased salinity causes floods in low areas, impacts tourist demand, and is a barrier to transportation' (B19, interview, 2016). Or 'Sea level rise causes inundation of islands, coastal areas and many lower places leading to decreasing number of tourists' (L01, interview, 2016)

And 'Sea level rise impacts the tourism resources. It leads to the decrease in attractiveness of destinations' (L08, interview, 2016)

\subsection{Level of Climate Change Impacts to Tourism Sector in the Mekong Delta}

Climate change impacts may vary depending on micro-climates in particular areas. Sea level rise, inundation and typhoons have been found to have a big impact on coastal and low-elevation deltas (Fashae \& Onafeso, 2011; Ghodrati, Alemi Safaval, \& Lashteh Neshaei, 2016; Goharnejad, Shamsai, \& Hosseini, 2013) while the effects of temperature and rainfall variations pose high risks to mountainous areas (Bhatti, Koike, \& Shrestha, 2016; Briner, Elkin, \& Huber, 2013; Pina Poujol, 2013). In the following part of this study the author examines the level of impact of climate change to the tourism sector in the region from three principal stakeholders' perspectives: tourism authorities, tourism business and tourists.

Fieldwork observations indicate that despite the fact that climate change directly impacts their daily activities the business sector still lacks awareness on the issue. They do not have any plans if a climate incident happens. Meanwhile, tourists, especially international tourists, have more awareness on the issue, at least at the global scale. Regardless, both domestic and international tourists are not local and they only experience small 'snap-shot' of climate impacts, without being able to comment on their longitudinal aspects (Table 4).

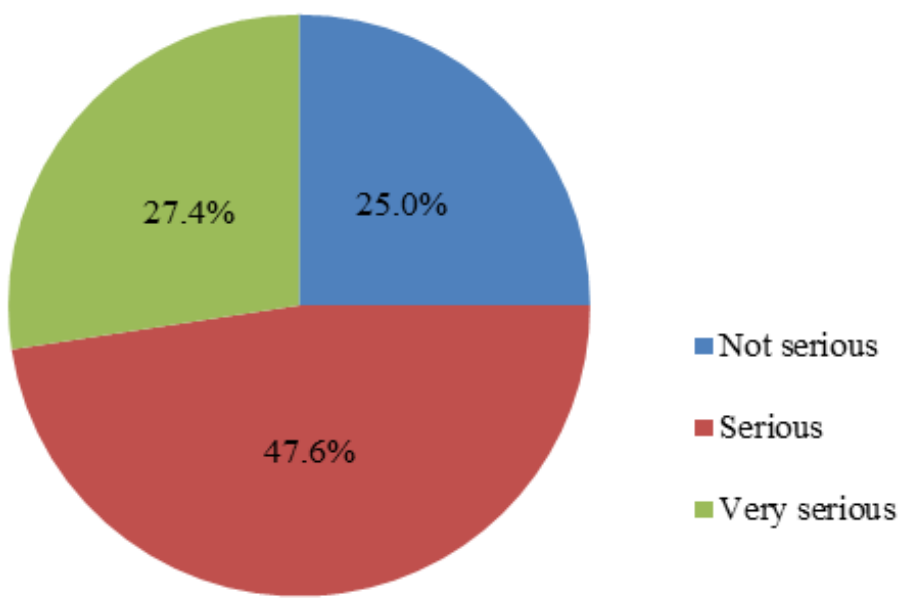

Figure 3. A pie chart showing questionnaire responses to the question: level impacts of climate change to local tourism? $(\mathrm{n}=124)$

Source: Questionnaire interview in 2016

The questionnaire investigated the degree of seriousness that the principal stakeholders accorded to climate change effects on the tourism sector. The study asked the question: in your experience, how serious are the impacts of climate change to your business/tourism enterprise? The responses are indicated in Figure 3. Responding to this question, $25.0 \%$ people thought that the impacts of climate change to tourism sector are not serious while the majority (75.0\%) agree that climate change seriously impacts. Overall, this simple query suggests that observed threats posed by climate change to the tourism industry in the Mekong Delta are readily apparent enough that three-quarters of the respondents are aware that it is a problem. 
Table 3. Impacts of climate change to local tourism by group $(n=124)$

\begin{tabular}{llllll}
\hline \multirow{2}{*}{ Group } & & Not serious & Serious & Very serious & Total \\
\cline { 3 - 6 } & Business & 13 & 14 & 9 & 30 \\
& Authorities & 4 & 9 & 2 & 15 \\
\multirow{2}{*}{ Total } & International tourists & 0 & 18 & 18 & 36 \\
\hline Chi-square test: & Domestic tourists & 31 & 59 & 11 & 43 \\
\end{tabular}

Source: Questionnaire interview in 2016

Across the different stakeholder groups, however, there are some differences in the perceived seriousness and imminence of the threats. There is a significant meaning between groups of respondents and how their evaluations on climate change effects.

Table 4 describes variations in the perceptions of stakeholder groups in the tourism industry in the Mekong Delta. International tourists who have fewer connections with local businesses, as well as less access to regional climate change information evaluate Mekong Delta tourism as under serious threat from climate change. Thirty-six out of thirty-six international tourists evaluated Mekong Delta tourism as seriously or very seriously threatened by the effects from climate change. In contrast, nearly one-third (14 out of 43) domestic tourists replied that the impact of climate change to the tourism sector in the region is not serious.

Another surprising finding from Table 4 is that authorities and businesses seem to have a subjective perspective about climate change impacts. Nearly one-third (4 out of 15) of the tourism authorities, who are arguably the most knowledgeable in the field, were of the opinion that climate change is not a serious problem for local tourism. Further, nearly a third (13 out of 45) of tourism business leaders who are well educated contend that climate change is not a serious problem for their businesses. While tourism business is the principal mode of participation in the local tourism system this figure raises a critical problem in terms of climate change awareness education for this sector. Once again, climate change awareness education issues have to be considered in the future for tourism stakeholders in the area.

Although the difference between international and domestic tourists, businesses and government authorities perception on climate change this result may be explain by the Variable Model (Arlt, Hoppe, \& Wolling, 2011). From this model peoples' climate change knowledge is influenced by many factors such as the availability of climate information, economic conditions and social influences. International tourists' awareness of global climate change scenarios accounts for their abilities to apply such scenarios, at least informally to sectors within Vietnam. The outcome of the questionnaire shows that most international tourists come from developed countries where climate change features heavily in the media and formal education.

From statistics in the Mekong Delta, tourism authorities have highest evaluation of climate change impacts, followed by businesses and domestic tourists. This finding is in line with the findings from Maponya, Mpandeli, and Oduniyi (2013) and Nzeadibe, Egbule, Chukwuone, and Agu (2011) that availability of information and level of education would decide ones evaluation on an issue. In this study, tourism authorities who have access to more information on the climate-tourism relation, as well as higher quality knowledge, and are experts in the field tend to have a negative outlook of the impact of climate change on regional tourism.

Literature shows that the role of tourists is mostly neglected in studies of impacts of climate change on the tourism sector. To bridge that gap this study asked tourists the question: Do you know Mekong Delta is one of the regions that have strong impacts from climate change? One third of the tourists were not aware that the Mekong Delta experiences strong impacts from climate change while the other two thirds of tourist respondents were aware of the issue. Looking at data it can be concluded that tourists are strongly aware of climate change impacts. This statistic could be explained due to respondents in this question are tourists who are knowledgeable.

Drawing together all the questionnaire data, Table 5 presents a matrix illustrating the level of impacts of climate change factors to tourism resources. There are five impact factors (Temperature, rain fall, sea level rise, storm and salinity) and three levels (High, medium and low). This has a very important implication as it sets foundation for conducting any further research about climate change impacts on tourism in the Mekong Delta. 
Table 4. Level of climate change impact to tourism resources in the Mekong Delta

\begin{tabular}{|c|c|c|c|c|c|}
\hline \multirow[t]{2}{*}{ RESOURCES } & \multicolumn{5}{|l|}{ Impact factors } \\
\hline & Temperature & $\begin{array}{l}\text { Rain } \\
\text { fall }\end{array}$ & $\begin{array}{ll}\text { Sea } & \text { level } \\
\text { rise } & \end{array}$ & Storm & Salinity \\
\hline \multicolumn{6}{|c|}{$\begin{array}{l}\text { National parks, biosphere reserve/conservation } \\
\text { areas }\end{array}$} \\
\hline \multicolumn{6}{|l|}{ Fruit gardens } \\
\hline \multicolumn{6}{|l|}{ Rivers, canals and islets } \\
\hline \multicolumn{6}{|l|}{ Islands and beaches } \\
\hline \multicolumn{6}{|l|}{ Floating markets } \\
\hline \multicolumn{6}{|l|}{ Khmer pagodas } \\
\hline \multicolumn{6}{|l|}{ Kinh Pagodas-temples } \\
\hline \multicolumn{6}{|l|}{ Don ca tai tu (traditional music) } \\
\hline \multicolumn{6}{|l|}{ Foods } \\
\hline \multicolumn{6}{|l|}{ Culture sites } \\
\hline \multicolumn{6}{|l|}{ Museums } \\
\hline \multicolumn{6}{|l|}{ Culture festivals } \\
\hline Traditional handicraft villages & & & & & \\
\hline
\end{tabular}

Impact levels

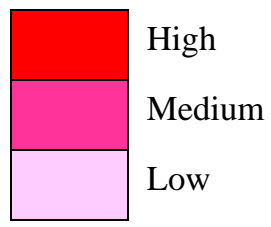

Source: Author's own work

From above matrix, natural tourism resources such as national parks, biosphere reserve areas and conservation areas, fruit gardens, rivers, canals and islets, islands and beaches are more vulnerable than culture resources. Sea level rise and storm events have an intensive influence on tourism resources. However, wider impacts of climate change on all tourism resources are recognized.

\subsection{Impacts of Climate Change to Tourism Resources in the Mekong Delta}

Climate conditions have a significant impact to creation and maintaining tourism resources. Therefore, any change in climate conditions may lead to the change in these resources as well as tourism demand and tourism season ( $\mathrm{Yu}$, Schwartz, \& Walsh, 2009). A range of examples validate the existence of the negative effects of changing climate upon tourism resources. For instance, change in climate may lead to coral bleaching (Cheablam \& Shrestha, 2014), snow melting (Buckley, 2017), beach erosion (Pendleton et al., 2011), decrease biodiversity (Vogiatzakis, Mannion, \& Sarris, 2016) and wetland conservation loses (Wall, 1998).

To exanimate the vulnerability of tourism resources in the Mekong Delta, this study conducted a surveying of authorities' and tourist's perception about the vulnerability level of principal tourism resources from climate change. These consist of natural and cultural resources such as fruit gardens, orchards, floating markets, pagodas, temples, islets and conservation areas. The outcomes are presented in Table 6. As far as the scientific literature is concerned, fruit gardens/orchards and conservation areas are the most vulnerable. Around $90 \%$ of valid respondents indicated that these resources are at vulnerable level and above. Islets around the region are also much vulnerable because around $75 \%$ of valid responses indicate that this resource is at more vulnerable level and above. On the other hand, pagodas and temples are a less vulnerable category. More than 55\% of valid respondents agree they are less vulnerable or only somehow vulnerable. This could be explained as pagodas and temples are humanly-made affording people some control over the construction process and conservation process, hence, decreasing some risk from climate change. 
Table 6. Level of vulnerable of tourism resources $(\%),(n=94)$

\begin{tabular}{|c|c|c|c|c|c|}
\hline & $\begin{array}{l}\text { Fruit gardens } \\
\text { Orchards }\end{array}$ & $\begin{array}{l}\text { Floating } \\
\text { markets }\end{array}$ & $\begin{array}{l}\text { Pagodas } \\
\text { and temples }\end{array}$ & Islets & $\begin{array}{l}\text { Conservation } \\
\text { areas }\end{array}$ \\
\hline Less vulnerable & 3.2 & 3.2 & 26.6 & 6.4 & 5.3 \\
\hline Somehow vulnerable & 2.1 & 8.5 & 29.8 & 9.6 & 1.1 \\
\hline Vulnerable & 16.0 & 17.0 & 14.9 & 7.4 & 9.6 \\
\hline Rather vulnerable & 39.4 & 45.7 & 7.4 & 33.0 & 31.9 \\
\hline Very vulnerable & 39.4 & 18.1 & 13.8 & 34.0 & 47.9 \\
\hline Not available & 0 & 7.4 & 7.4 & 9.6 & 4.3 \\
\hline
\end{tabular}

Source: Questionnaire interview in 2016

Threats to floating markets are a current big debate in the tourism industry recently. Floating markets are one of the main attractions in the delta tourism. Although floating markets are not impacted by climate change directly factors such as sea level rise could have the secondary effect of changing livelihoods and natural resources that are current market commodities. Consequently, it is evaluated rather sensitive to climate impacts. Over $80 \%$ of valid responses agree that floating markets are at a vulnerable level and above.

To have a clearer view on the issue of how is vulnerable of tourism resource in the region this study calculates the mean point of the statistic. The result outcome represents that almost all tourism resources in the area are at the high vulnerable level with the mean value from 3.0 to 4.0. Specifically, tourists conservation areas $(\mathrm{M}=4.29)$ and fruit gardens/orchards $(\mathrm{M}=4.10)$ have the highest vulnerability level. Islets $(\mathrm{M}=4.07)$ and floating markets $(\mathrm{M}=3.89)$ are at a little bit lower level but this mean is still relatively giant. Pagodas and temples (2.74) are at the lowest level of vulnerability but have biggest standard deviation $(\mathrm{s}=1.619)$.

Hence, from above responses, it is recognized that climate change already has a variety of effects on the tourism resources and presents barriers for tourism activities in the region. An important concern is that if climate change results in severe impacts to tourism, tourist numbers will drop. To test this hypothesis a three-point Likert style scale was used to examine the return capacity of tourists in the changing climate condition of the region. The results are shown in Table 5. In general, tourists showed relatively negative responses when asked if they would return should there be any change of climate conditions. Only $10.1 \%, 11.4 \%, 19.0 \%$ and $25.3 \%$ tourist will comeback if there are more storms, floating markets disappear, fruit gardens are damaged, conservation areas are damaged and there is a lack of fresh water, respectively. A more positive response rate was from another group. 53.2\%, 50.6\% and 31.6\% of tourist will return if temperatures increase, rainfall happens irregularly and inundation due to sea level rise or floods occurs, respectively. Therefore, mitigation and adaptation are the principal approach for tourism-climate change tackle in the Mekong Delta.

Table 5. Will you return and recommend for others to visit Mekong Delta if negative factors of climate change appear in the future $(\%),(\mathrm{n}=79)$

\begin{tabular}{llllllll}
\hline & $\begin{array}{l}\text { Temperature } \\
\text { increasing }\end{array}$ & $\begin{array}{l}\text { Rainfall } \\
\text { irregularly }\end{array}$ & $\begin{array}{l}\text { Inundation } \\
\text { due to sea } \\
\text { level rise or } \\
\text { flood }\end{array}$ & $\begin{array}{l}\text { More } \\
\text { storms }\end{array}$ & $\begin{array}{l}\text { Lack } \\
\text { of } \\
\text { fresh } \\
\text { water }\end{array}$ & $\begin{array}{l}\text { Fruit gardens, } \\
\text { conservation } \\
\text { areas damage }\end{array}$ & $\begin{array}{l}\text { Floating } \\
\text { market } \\
\text { disappear }\end{array}$ \\
\hline No & 25.3 & 29.1 & 41.8 & 57.0 & 58.2 & 48.1 & 68.4 \\
Yes & 53.2 & 50.6 & 31.6 & 10.1 & 25.3 & 19.0 & 11.4 \\
Unsure & 21.5 & 20.3 & 26.6 & 32.9 & 16.5 & 32.9 & 20.3 \\
Total & 100.0 & 100.0 & 100.0 & 100.0 & 100.0 & 100.0 & 100.0 \\
\hline
\end{tabular}

Source: Questionnaire interview in 2016

\subsection{Impacts of Climate Change to Tourism Infrastructures in the Mekong Delta}

Tourism infrastructures such as accommodation, transportation and restaurants are important components of the tourism system. Questionnaire surveys, in-depth interviews, as well as observations from the field visits indicate that climate change has a huge influence on hotels, roads, tourist wharfs, restaurants and other tourist facilities in the region.

In depth interview and fieldwork observations indicate that due to an absence of strategic planning for regional accommodation options, this sector faces an enormous problem from storm surges, temperature increase, and especially sea level rise. As far as tourism accommodations are concerned a direct and indirect effect from climate change would be felt. The direct severe effect from climate change to accommodation is sea level rise. Sea level rise would cause 
inundation of accommodations; inundation of tourist sceneries; a barrier for logistical access to activities; obstruction to food provision and growing areas as well as entertainment services and would offer a bad vacation experience for tourists. These limitations of sea level rise may lead to a decrease in the demand of vacations and reduce the satisfaction of tourists.

The indirect effects of climate change on tourism may result in an increase of energy consumption (for such things as air conditioning, boat hire for efficient transport etc.) and therefore reduce the cost efficiency of tourism activities. More risks mean more investment in prevention and protection. Temperature increases lead to more consumption of water and electricity. Salinity may damage facilities and increase the cost of fresh water production, as well as reduced crop productivity. Increasing frequency of storms and intensive abnormal rain episodes may suddenly damage tourism facilities on a large scale. In the questionnaires, nearly $70 \%$ of respondents commented that tourism utilities may get damaged by climate change and $40 \%$ of them are already experiencing the bad effect of poor weather on their tourism facilities.

The interview session also recorded a number of comments about the bad influence of climate change upon tourism facilities. Almost all respondents in the interviews mention one or more negative influences of climate change consequences to their tourism facilities. Their claims the problem as the following:

'Hot weather leads to extra use of energy for air conditioner' (B15, interview, 2016)

'Direct impact to infrastructure, especially the transport system, site infrastructure' (B09, interview, 2016)

'Temperature increase lead to energy and water consumption increase' (B17, interview, 2016)

'Impact to tourism facilities: hot weather, storm, extreme weather impacts to transportation and excursion journey. Impact to transport facilities, public facilities, tourism infrastructure' (L03, interview, 2016)

'Extreme weather and sea level rise impact to infrastructure, facilities and cultural remnants, especially coastal areas' (L10, interview, 2016)

'The equipment of hotel gets wet and damaged' (B02, interview, 2016).

'Temperature increases suddenly, hot weather leads to the significant consumption of energy. In the rainy season, the rain also comes suddenly causing damage to infrastructures such as: walls paint get damaged, rusting of furniture' and 'Climate change causes floods making it difficult for tourists to travel around, also causes unexpected delay for airlines and busses' (B05, interview, 2016)

'Sea water intrusion causes damage to fruits and impact the ecotourism based on fruit gardens' (L06, interview, 2016).

Above quotations shown that there are a wide range of problems of climate change on the tourism sector in the Mekong Delta. Respondents normally observed the direct impacts of climate change. Effects of climate change to tourism facilities and tourism resources received much attention of respondents. Due to the fact that tourism businesses in the Mekong Delta are almost small businesses the financial instable would cause a big challenge for them. Hence, the financial lost from climate change was the main concern of tourism businesses in the region. Because tourism infrastructure is one of the most important components of an effective tourism business its impact to this sector has to be carefully planned into adaptation scenarios.

\section{Conclusion}

To sum up, the impact of climate change on the tourism sector in the Mekong Delta is considered high. Interestingly, stakeholders in the survey considered some threats to be more important than reported in climate change literature meaning that there exist variations between evidence-based science and observational-based local knowledge. Tourists evaluated the possible impacts of climate change threats during their trip in the Mekong Delta at the medium level in a five-point Likert style scale.

The study also pointed out that climate change is real and poses powerful impacts on the tourism industry in the Mekong Delta of Vietnam. The most important threat is sea level rise. However, other climate change consequences also should be considered in the climate change evaluation and adaptation for the region. Tourism resources and facilities in the region would suffer to an enormous influence in any change of climate. A general planning strategy in the region is absent, a situation that needs rectifying. Therefore, a complete national climate change program target on tourism sector must be introduced for a sustainable regional tourism industry. 


\section{References}

Arlt, D., Hoppe, I., \& Wolling, J. (2011). Climate change and media usage: Effects on problem awareness and behavioural intentions. International Communication Gazette, 73(1-2), 45-63. https://doi.org/10.1177/1748048510386741

Aylen, J., Albertson, K., \& Cavan, G. (2014). The impact of weather and climate on tourist demand: the case of Chester Zoo. Climatic Change, 127(2), 183-197. https://doi.org/10.1007/s10584-014-1261-6

Becken, S. (2005). Harmonising climate change adaptation and mitigation: The case of tourist resorts in Fiji. Global Environmental Change, 15, 381-393. https://doi.org/10.1016/j.gloenvcha.2005.08.001

Bhatti, A. M., Koike, T., \& Shrestha, M. (2016). Climate change impact assessment on mountain snow hydrology by water and energy budget-based distributed hydrological model. Journal of Hydrology, 543, 523-541. https://doi.org/10.1016/j.jhydrol.2016.10.025

Bicknell, S., \& McManus, P. (2006). The canary in the coalmine: Australian ski resorts and their response to climate change. Geographical Research, 44, 386-400. https://doi.org/10.1111/j.1745-5871.2006.00409.x

Bigano, A., Bosello, F., Roson, R., \& Tol, R. (2008). Economy-wide impacts of climate change: A joint analysis for sea level rise and tourism. Mitigation and Adaptation Strategies for Global Change, 13(8), 765-791. https://doi.org/10.1007/s11027-007-9139-9

Briner, S., Elkin, C., \& Huber, R. (2013). Evaluating the relative impact of climate and economic changes on forest and agricultural ecosystem services in mountain regions. Journal of Environmental Management, $129,414$. https://doi.org/10.1016/j.jenvman.2013.07.018

Buckley, R. (2017). Perceived Resource Quality as a Framework to Analyze Impacts of Climate Change on Adventure Tourism: Snow, Surf, Wind, and Whitewater. Tourism Review International, $21(3), 241$. https://doi.org/10.3727/154427217X15022104437729

Buzinde, C. N., Manuel-Navarrete, D., Kerstetter, D., \& Redclift, M. (2010). Representations and adaptation to climate change. Annals of Tourism Research, 37, 581-603. https://doi.org/10.1016/j.annals.2009.10.018

Buzinde, C. N., Manuel-Navarrete, D., Yoo, E. E., \& Morais, D. (2010). Tourists' perceptions in a climate of change: Eroding destinations. Annals of Tourism Research, 37, 333-354. https://doi.org/10.1016/j.annals.2009.09.006

Cheablam, O., \& Shrestha, R. P. (2014). Climate Change Trends and Its Impact on Tourism Resources in Mu Ko Surin Marine National Park, Thailand. Asia Pacific Journal of Tourism Research, 20(4), 1-20. https://doi.org/10.1080/10941665.2014.904803

Coghlan, A., \& Prideaux, B. (2009). Welcome to the wet tropics: The importance of weather in reef tourism resilience. Current Issues in Tourism, 12, 89-104. https://doi.org/10.1080/13683500802596367

Coombes, E. G., \& Jones, A. P. (2010). Assessing the impact of climate change on visitor behaviour and habitat use at the coast: A UK case study. Global Environmental Change, 20, 303-313. https://doi.org/10.1016/j.gloenvcha.2009.12.004

Craig, C. A., \& Feng, S. (2018). A temporal and spatial analysis of climate change, weather events, and tourism businesses. Tourism Management, 67, 351-361. https://doi.org/10.1016/j.tourman.2018.02.013

Dawson, J., \& Scott, D. (2010). Systems analysis of climate change vulnerability for the US Northeast ski sector. Tourism and Hospitality, Planning and Development, 7, 219-235. https://doi.org/10.1080/1479053X.2010.502383

Fashae, O. A., \& Onafeso, O. D. (2011). Impact of climate change on sea level rise in Lagos, Nigeria. International Journal of Remote Sensing, 32(24), 9811-9819. https://doi.org/10.1080/01431161.2011.581709

Ghodrati, A., Alemi, S. P., \& Lashteh, N. M. A. (2016). Climate Change Impact of the Caspian Sea Level Changes in the Quaternary Sediment. Frontiers in Environmental Engineering, 5(0), 1. https://doi.org/10.14355/fiee.2016.05.001

Goharnejad, H., Shamsai, A., \& Hosseini, S. A. (2013). Vulnerability assessment of southern coastal areas of Iran to sea level rise: evaluation of climate change impact. Oceanologia, 55(3), 611-637. https://doi.org/10.5697/oc.55-3.611

Griffis, R. E., \& Howard, J. E. (2013). Oceans and Marine Resources in a Changing Climate A Technical Input to the 2013 National Climate Assessment: Washington, DC : Island Press/Center for Resource Economics : Imprint: Island Press, 2013. https://doi.org/10.5822/978-1-61091-480-2 
Hall, C. M. (2006). New Zealand tourism entrepreneur attitudes and behaviours with respect to climate change adaptation and mitigation. International Journal of Innovation and Sustainable Development, 1, 229-237. https://doi.org/10.1504/IJISD.2006.012424

Hamilton, J. M. (2007). Coastal landscape and the hedonic price of accommodation. Ecological Economics. Ecological Economics, 62, 594-602. https://doi.org/10.1016/j.ecolecon.2006.08.001

Hendrikx, J., Zammit, C., Hreinsson, E., \& Becken, S. (2013). A comparative assessment of the potential impact of climate change on the ski industry in New Zealand and Australia. Climatic Change, 119(3), 965-978. https://doi.org/10.1007/s10584-013-0741-4

ICEM. (2013). Mekong Adaptation and Resilience to Climate Change (ARCC) USAID Mekong Adaptation and Resilience to Climate Change Project. Hanoi: International Centre for Environmental Management.

IPCC. (2001). Climate Change 2001: Impacts, Adaptation, and Vulnerability. Contribution of Working Group II to the Third Assessment Report of the Intergovernmental Panel on Climate Change: Cambridge University Press.

James, K. (2018). Successful Strategies to Sustain Profits from Tourism Following a Hurricane. In D. Samora, I. Williams \& R. Dwyer (Eds.): ProQuest Dissertations Publishing.

Jones, B., Scott, D., \& Khaled, H. A. (2006). Implications of climate change for outdoor event planning: A case study of three special events in Canada's National Capital Region. Event Management, 10(1), 63-76. https://doi.org/10.3727/152599506779364615

Kaján, E., \& Saarinen, J. (2013). Tourism, climate change and adaptation: a review. Current Issues in Tourism, 16(2), 167-195. https://doi.org/10.1080/13683500.2013.774323

Lew, A., Hall, C. M., \& Timothy, D. J. (2008). World geography of travel and tourism: a regional approach: Butterworth-Heinemann.

Lewsey, C., Cid, G., \& Kruse, E. (2004). Assessing climate change impacts on coastal infrastructure in the Eastern Caribbean. Marine Policy, 28(5), 393-409. https://doi.org/10.1016/j.marpol.2003.10.016

Maponya, P., Mpandeli, S., \& Oduniyi, S. (2013). Climate Change Awareness in Mpumalanga Province, South Africa. Journal of Agricultural Science, 5(10), 273-282. https://doi.org/10.5539/jas.v5n10p273

Mekong River Commission data and information services. (2017). MRC DSF / Toolbox: Application in LMB. In M. R. Commission (Ed.). Bangkok.

Ministry of Natural Resources and Environment. (2008). National target program to response to climate change. Ha Noi: Minstry of Natural Resources and Environment.

Ministry of Natural Resources and Environment. (2016). Climate change and sea level rise scenarios for Vietnam. Ha Noi.

Moreno, A., \& Becken, S. (2009). A climate change vulnerability assessment methodology for coastal tourism. Journal of Sustainable Tourism, 17, 473-488. https://doi.org/10.1080/09669580802651681

Neffati, M., Sriti, J., Hamdaoui, G., Kchouk, M. E., \& Marzouk, B. (2011). Salinity impact on fruit yield, essential oil composition and antioxidant activities of $\mathrm{C}$ oriandrum sativum fruit extracts. Food Chemistry, 124(1), 221-225. https://doi.org/10.1016/j.foodchem.2010.06.022

NSW office of Environment and Heritage. (2018). all about salinity. Retrieved 11 January 2018. Retrieved from http://www.environment.nsw.gov.au/resources/salinity/allaboutsalinity.pdf

Nzeadibe, T. C., Egbule, C. L., Chukwuone, N. A., \& Agu, V. C. (2011). Climate change awareness and adaptation in the Niger Delta Region of Nigeria. African Technology Policy Studies Network, Nairobi.

Pang, S. F. H., McKercher, B., \& Prideaux, B. (2012). Climate Change and Tourism: An Overview. Asia Pacific Journal of Tourism Research, 18(1-2), 4-20. https://doi.org/10.1080/10941665.2012.688509

Pendleton, L., King, P., Mohn, C., Webster, D., Vaughn, R., \& Adams, P. (2011). Estimating the potential economic impacts of climate change on Southern California beaches. Climatic Change, 109(Supplement 1), 277-298. https://doi.org/10.1007/s10584-011-0309-0

Pentelow, L., \& Scott, D. J. (2011). Aviation's inclusion in international climate policy regimes: Implications for the Caribbean tourismindustry. Journal of Air Transport Management, 17, 199-205. https://doi.org/10.1016/j.jairtraman.2010.12.010 
Perry, A. H. (2006). Will predicted climate change compromise the sustainability of Mediterranean tourism? Journal of Sustainable Tourism, 14, 367-275. https://doi.org/10.2167/jost545.0

Pham, P. N. (2013). New year report 2013: Mekong Delta Tourism Association.

Pickering, C. M., \& Buckley, R. C. (2010). Climate response by the ski industry: The shortcomings of snowmaking for Australian resorts. Ambio, 39, 430-438. https://doi.org/10.1007/s13280-010-0039-y

Pina, P. P. (2013). Impact of Mountain Pine Beetle Attack on Water Balance of Lodgepole Pine Forests in Alberta. In U. Silins (Ed.): ProQuest Dissertations Publishing.

Quante, M. E., \& Colijn, F. E. (2016). North Sea Region Climate Change Assessment. Cham: Springer International Publishing : Imprint: Springer, 2016. https://doi.org/10.1007/978-3-319-39745-0

Rosselló-Nadal, J., Riera-Font, A., \& Cárdenas, V. (2011). The impact of weather variability on British outbound flows. Climatic Change, 105(1), 281-292. https://doi.org/10.1007/s10584-010-9873-y

Schleupner, C. (2008). Evaluation of coastal squeeze and its consequences for the Caribbean island Martinique. Ocean and Coastal Management, 51, 383-390. https://doi.org/10.1016/j.ocecoaman.2008.01.008

Scott, D. (2011). Why sustainable tourism must address climate change. Journal of Sustainable Tourism, 19(1), 17-34. https://doi.org/10.1080/09669582.2010.539694

Scott, D., \& Becken, S. (2010). Adapting to climate change and climate policy: progress, problems and potentials. Journal of Sustainable Tourism, 18(3), 283-295. https://doi.org/10.1080/09669581003668540

Scott, D., Hall, C. M., \& Gössling, S. (2012). Tourism and climate change : impacts, adaptation and mitigation. London, New York: London, New York : Routledge. https://doi.org/10.4324/9780203127490

Scott, D., McBoyle, G., Minogue, A., \& Mills, B. (2006). Climate change and the sustainability of ski-based tourism in eastern North America: A reassessment. Journal of Sustainable Tourism, 14(4), 376-398. https://doi.org/10.2167/jost550.0

Scott, D., Wall, G., McBoyle, G., Hall, C. M., \& Higham, J. (2005). Tourism, recreation and climate change. Clevedon: Channelview Press.

Simpson, M. C., Gössling, S., Scott, D., Hall, C. M., \& Gladin, E. (2008). Climate change adaptation and mitigation in the tourism sector: Frameworks, tools and practices. UNEP, University of Oxford, UNWTO, WMO: Paris, France.

Steiger, R., \& Stötter, J. (2013). Climate Change Impact Assessment of Ski Tourism in Tyrol. Tourism Geographies, 15(4), 577-600. https://doi.org/10.1080/14616688.2012.762539

Stewart, E. J., Dawson, J., \& Draper, D. (2011). Cruise-ship tourism in Nunavut, Arctic Canada: An analysis of resident perspectives. Journal of Hospitality and Tourism Management, 18, 388-404. https://doi.org/10.1375/jhtm.18.1.95

Surugiu, C., \& Surugiu, M. R. (2012). The Assessmentof Climate Change Impact on the Romanian Seaside Tourism. Economic Research-Ekonomska IstraEsivanja, 25(4), 959-972. https://doi.org/10.1080/1331677X.2012.11517541

TITC. (2014). Tourism and climate change: adapt with global challences: Vietnam National Administration of Tourism.

Tran, T. P. H. (2015). Tourism Mekong Delta in the context of international economic intergration. Retrieved from http://www.saigonact.edu.vn/

Turton, S., Dickson, T., Hadwen, W., Jorgensen, B., Pham, T., Simmons, D., ... Wilson, R. (2010). Developing an approach for tourism climate change assessment: Evidence from four contrasting Australian case studies. Journal of Sustainable Tourism, 18, 429-447. https://doi.org/10.1080/09669581003639814

UNWTO-UNEP-WMO. (2008). Davos declaration. Climate change and tourism: Responding to global challengs.

UNWTO, UNEP, \& WMO. (2008). Climate Change and Tourism: Responding to Global Challenges. UNWTO, Madrid and UNEP, Paris.

Vietnam Tourism Institute. (2010). Mekong Delta master plan for tourism development to 2020 (pp. 100): Vietnam Tourism Institute.

Vogiatzakis, I., Mannion, A., \& Sarris, D. (2016). Mediterranean island biodiversity and climate change: the last 10,000 years and the future. Biodiversity \& Conservation, 25(13), 2597-2627. https://doi.org/10.1007/s10531-016-1204-9

Wabnitz, C., Lam, V., Reygondeau, G., Teh, L., Al-Abdulrazzak, D., Khalfallah, M., ... Cheung, W. (2018). Climate change impacts on marine biodiversity, fisheries and society in the Arabian Gulf. PLoS One, 13(5), e0194537. https://doi.org/10.1371/journal.pone.0194537 
Wall, G. (1998). Implications of global climate change for tourism and recreation in wetland areas. Climatic Change, 40(2), 371-389. https://doi.org/10.1023/A:1005493625658

Weaver, D. (2011). Can sustainable tourism survive climate change? Journal of Sustainable Tourism, 19(1), 5-15. https://doi.org/10.1080/09669582.2010.536242

Yu, G., Schwartz, Z., \& Walsh, J. (2009). A weather-resolving index for assessing the impact of climate change on tourism related climate resources. Climatic Change, 95(3), 551-573. https://doi.org/10.1007/s10584-009-9565-7

\section{Copyrights}

Copyright for this article is retained by the author(s), with first publication rights granted to the journal.

This is an open-access article distributed under the terms and conditions of the Creative Commons Attribution license (http://creativecommons.org/licenses/by/4.0/). 